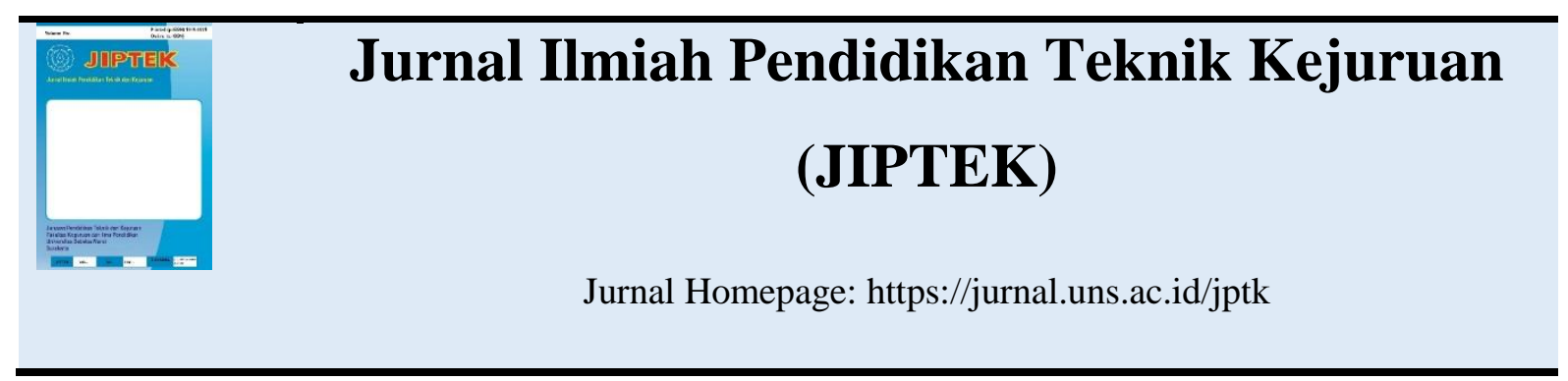

\title{
PENERAPAN PROJECT BASED LEARNING UNTUK MENINGKATKAN AKTIVITAS DAN KOMPETENSI INSTALASI SISTEM OPERASI BERBASIS GUI DAN CLI PADA SISWA KELAS X TKJ DI SMK N 1 SAWIT
}

\author{
Pinasti Nur Handayaningtyas ${ }^{1}$, Basori ${ }^{2}$, AG. Tamrin ${ }^{3}$ \\ ${ }^{1}$ SMKN 1 Sawit, Boyolali \\ ${ }^{2,3}$ Program Studi Pendidikan Teknik Informatika dan Komputer, FKIP, \\ Universitas Sebelas Maret Surakarta \\ Email: basori@staff.uns.ac.id
}

\begin{abstract}
ABSTRAK
Penelitian ini bertujuan untuk mengetahui apakah penerapan project based learning dapat meningkatkan aktivitas dan kompetensi belajar siswa dalam Instalasi Sistem Operasi Berbasis GUI ( Graphical User Interface) dan CLI ( Command Line Interface) kelas X TKJ SMK N 1 Sawit. Penelitian ini menggunakan metode Penelitian Tindakan Kelas (PTK) yang dilaksanakan sebanyak dua siklus dimana masing - masing siklus dilakukan dengan empat tahapan, yaitu : (1) tindakan perencanaan; (2) tindakan pelaksanaan; (3) tindakan observasi; dan (4) refleksi. Subjek penelitian adalah siswa kelas X TKJ 3 di SMK N 1 Sawit sebanyak 34 siswa. Teknik pengumpulan data menggunakan lembar observasi, wawancara, instrumen tes dan teknik analisis data. Hasil penelitian, menunjukkan : (1) Aktivitas siswa dalam mengikuti pembelajaran mengalami peningkatan pada pra siklus sebesar 32,35\% menjadi $58,82 \%$ pada siklus I dan pada siklus II meningkat menjadi 82,35\%. (2) Kompetensi siswa dalam pembelajaran terdisi dari 3 ranah yaitu masing - masing ranah meengalami peningkatan sebagai berikut: (a) Ranah Kognitif dari pra siklus sebesar 11,76\% menjadi 26,47\% pada siklus I dan siklus II meningkat menjadi sebesar 47,05\%.Ranah Afektif dari pra siklus sebesar 32,35\% menjadi 53,29\% pada siklus I dan pada siklus II meningkat menjadi sebesar 76,47\%. (c) Ranah Psikomotorik dari pra siklus sebesar $44,11 \%$ menjadi $79,41 \%$ pada siklus I dan pada siklus II meningkat menjadi $82,35 \%$.
\end{abstract}

Kata kunci: Project based learning, Aktivitas, kompetensi, GUI, CLI

\section{ABSTRACT}

This study aims to know the implementation of project-based learning to improve the activity and competence of learning in the programming language and graphical user interface class X TKJ SMK $N 1$ Sawit. The method research was Classroom Action Research (PTK) which conducted every two cycles and each cycle was done by four stages: (1) planning; (2) implementation; (3) observation; and (4) reflection. The subjects of the study were students of class X TKJ 3 in SMK N 1 Sawit as many as 34 students. Technical data using observation data sheets, interviews, data analysis instruments. The result of the research showed: (1) student activity in learning development increased at $32,35 \%$ to $58,82 \%$ in cycle I and on the second cycle increased to 82,35\%. (2) The students' competence in learning is divided into 3 domains, each of which consists of (a) Cognitive domain from pre-cycle of $11,76 \%$ to $26,47 \%$ in cycle I and cycle II increase to paddy $47,05 \%$. The affective area from pre-cycles of $32.35 \%$ to $53.29 \%$ in cycle I and in cycle II increased to equal to $76.47 \%$. (c) Psychomotor domains from pre-cycles of $44.11 \%$ to $79.41 \%$ in cycle I and in cycle II increased to $82.35 \%$

Keywords: Project based learning, Activities, competence, GUI, CLI 


\section{PENDAHULUAN}

Menginstallasi sistem operasi berbasis GUI dan CLI adalah salah satu mata pelajaran untuk siswa Sekolah Menengah Kejuruan (SMK) program studi program keahlian Teknik Komputer dan Jaringan (TKJ). Hal ini karena mata pelajaran installasi sistem operasi berbasis GUI dan CLI mempelajari tentang perangkat lunak yang bertugas untuk melakukan kontrol dan manajemen perangkat keras dan juga operasioperasi dasar sistem, termasuk menjalankan software aplikasi seperti program-program pengolah data yang bisa digunakan untuk mempermudah kegiatan pengguna komputer yang menjadi dasar untuk siswa program studi keahlian teknologi informasi dan komunikasi.

Di SMK N 1 Sawit untuk program studi keahlian teknik komputer jaringan, mata pelajaran installasi sistem operasi berbasis GUI dan CLI ini akan membahas seluk beluk mengenai sistem operasi Windows dan Linux. Pada semester 2 yang akan dipelajari adalah sistem operasi Linux. Menurut penelitian awal yang dilaksanakan peneliti, masalah yang ada pada siswa kelas X TKJ 3 di SMK N 1 Sawit untuk mata pelajaran installasi sistem operasi berbasis GUI dan CLI adalah rendahnya aktivitas dan kompetensi belajar siswa dalam mengikuti proses pembelajaran. Hal ini ditunjukkan ketika proses belajar mengajar berlangsung, siswa melakukan aktivitas lain seperti membuka sosial media ataupun mengobrol dengan temannya. Berdasarkan data observasi aktivitas siswa yang menunjukkan bahwa aktivitas belajar siswa rendah dengan rata-rata sebesar $32,35 \%$. Capaian hasil belajar juga tidak maksimal yang ditunjukkan dari presentase kompetensi pada hasil belajar pada pratindakan sebesar $11,76 \%$ untuk ranah kognitif, 32,35\% ranah afektif, dan $44,11 \%$ ranah psikomotor. Berdasarkan masalah tersebut, maka perlu diterapkan model pembelajaran untuk meningkatkan aktivitas dan kompetensi belajar siswa dengan menerapkan model pembelajaran project based learning. Dengan model project based learningampu mendorong siswa untuk aktif, kreatif, dan juga produktif sehingga dapat meningkatkan hasil belajar secara optimal dan mampu menekankan pendekatan pembelajaran yang inovatif, pada belajar kontekstual melalui kegiatan- kegiatan yang kompleks. (CORD, 2001 ; Thomas, Mergendoller, \& Michaelson, 1999 ; Moss, VanDuze, Carol, 1998). Puji Astuti (2013, model pembelajaran dengan project based learning dapat meningkatkan aktivitas dan hasil belajar siswa pada materi pencemaran siswa kelas X6 SMA Negeri 4 Pekalongan Tahan 2012/2013. Model pembelajaran project based learning mampu mampu mendorong siswa untuk aktif, kreatif, dan juga produktif sehingga dapat meningkatkan hasil belajar secara optimal dan mampu menekankan pendekatan pembelajaran yang inovatif, pada belajar kontekstual melalui kegiatan - kegiatan yang kompleks. (CORD, 2001 ; Thomas, Mergendoller, \& Michaelson, 1999 ; Moss, Van-Duze, Carol, 1998). Sedangkan sistem operasi yang di gunakan adalah Linux, penggunaan Linux untuk mempermudah siswa dalam memahami materi terutama untuk materi sistem operasi berbasis CLI. Tujuan penelitian adalah, (1) untuk mengetahui apakah penerapan model pembelajaran project based learning dapat meningkatkan aktivitas belajar peserta didik 
kelas X TKJ di SMK Negeri 1 Sawit pada materi installasi sistem operasi berbasisGUI dan CLI, (2) untuk mengetahui apakah penerapan model pembelajaran project based learning dapat meningkatkan kompetensi belajar peserta didik kelas X TKJ di SMK Negeri 1 Sawit pada materi installasi sistem operasi berbasis GUI dan CLI. Model pembelajaran project based learning dapat mengubah hakikat hubungan antara guru dan pembelajar. Proyek dapat mereduksi kompetisi di dalam kelas dan mengarahkan pembelajar lebih kolaboratif daripada kerja sendiri-sendiri. Proyek juga dapat menggeser fokus pembelajaran dari mengingat fakta ke eksplorasi ide, (Kamdi, 2008: 6-15). $\quad$ Model pembelajaran ini bisa diterapkan untuk semua tingkatan kelas dan bidang materi pelajaran. Sintak model pembelajaran Project based learning yaitu (1) start with theessential question, (2) design a plan for the project , (3) create a schedule, (4) monitor the students and the progress of the project, (5) assess the outcome dan (6) evaluate the experience.

\section{METODE PENELITIAN}

Pendekatan penelitian yang digunakan adalah Penelitian Tindakan Kelas (PTK). Subjek penelitian ini adalah siswa kelas $X$ TKJ 3 SMK N 1 Sawit, yang berjumlah 34 siswa. Data yang dikumpulkan untuk kebutuhan penelitian ini terbagi dalam dua jenis yaitu data kualitatif dan data kuantitatif. Data kualitatif tersebut meliputi data hasil observasi dan wawancara seputar proses pembelajaran di kelas, sedangkan data kuantitatif berupa nilai hasil belajar siswa dari tiap siklus. Pengumpulan data yang digunakan dalam penelitian ini yaitu (1) wawancara, (2) metode observasi, (3) metode dokumentasi, dan (4) tes. Data yang telah dikumpulkan akan dianalisis dengan analisis komparatif yaitu membandingkan nilai dari setiap siklus pada tes hasil belajar dan deskriptif kualitatif berdasarkan pada hasil observasi untuk keaktifan belajar.

\section{HASIL PENELITIAN DAN PEMBAHASAN}

Pada penelitian ini dilaksanakan prasiklus sebelum melakukan tindakan penelitian. Pada pelaksanaan tahap ini dilakukan selama satu kali pertemuan. Tahap prasiklus dilaksanakan dengan tujuan untuk memperoleh gambaran awal hasil dari aktivitas dan kompetensi belajar siswa dalam pembelajaran installasi sistem operasi berbasis GUI dan CLI sebelum dilakukan tindakan penelitian serta untuk mengetahui perbandingan hasil pembelajaran antara metode konvensional dengan model project based learning. Tahap prasiklus dilaksanakan pada tanggal 27 April 2016 pukul 10.00 WIB sampai pukul 12.00 WIB pada Kompetensi Dasar (KD) "Menginstallasi Sistem Operasi berbasis GUI dan CLI'. Dalam tahap prasiklus diketahui bahwa kegiatan pembelajaran pada prasiklus ini masih berpusat pada guru, penggunaan media pembelajaran masih kurang, siswa juga terlihat kurang aktif mengikuti pelajaran.

Dari hasil observasi terhadap akvitas belajar siswa yang dilakukan, dari 5 aspek yang diamati yaitu (1) aspek visual, (2) aspek lisan, (3) aspek mendengarkan, (4) aspek menulis, (5) aspek mental, dan diketahui bahwa $29,41 \%$ dari jumlah siswa yaitu 34 siswa telah melakukan aktivitas visual, 14,70\% dari jumlah siswa telah melakukan aktivitas lisan, 52,94\% dari jumlah 
siswa telah melakukan aktivitas mendengarkan, $17,64 \%$ dari jumlah siswa telah melakukan aktivitas menulis, 23,52\% dari jumlah siswa telah melakukan aktivitas mental. Rata-rata ketuntasan untuk aktivitas belajar pada tahap prasiklus masih dibawah indikator keberhasilan penelitian yang diterapkan pada penelitian ini sebesar $75 \%$ yaitu hanya $47,05 \%$. Presentase ketuntasan hasil kompetensi belajar pada tahap prasiklus juga masih rendah, yaitu untuk ranah kognitif sebesar 32,35\% aktivitas belajar siswa, untuk kompetensi belajar siswa pada masing masing ranah yaitu $11,76 \%$ ranah kognitif, ranah afektif $32,35 \%$, dan ranah psikomotor $44,11 \%$.

Hasil wawancara yang telah dilakukan kepada guru mata pelajaran sistem operasi berbasis $G U I$ dan CLI kelas X TKJ di SMK N 1 Sawit dan siswa kelas X TKJ 3 di SMK N 1 Sawit pada tahap prasiklus diketahui pula bahwa dengan penerapan metode ceramah, aktivitas dan kompetensi belajar siswa masih rendaah sehingga hasil belajar siswa masih rendah. Hal ini dikarenakan selama pembelajaran siswa kurang aktif dalam merespon materi yang disampaikan dan melakukan hal-hal diluar proses pembelajaran seperti mengobrol atau bermain laptop. Selain itu juga siswa kurang memahami materi karena siswa kurang berminat terhadap metode ceramah yang diterapkan dan kurangnya media pembelajaran yang digunakan. Peneliti menerapkan model pembelajaran project based learning berdasarkan analisis pada tahap prasiklus yang telah dilakukan. Model pembelajaran project based learning dapat membantu siswa mempelajari materi installasi sistem operasi, khususnya pada Kompetensi Dasar "Melakukan installasi sistem operasi berbasis CLI pada Linux" yang akan dilaksanakan pada siklus I dan siklus II. Dalam penelitian ini yang bertindak sebagai pengajar adalah guru mata pelajaran installasi sistem operasi berbasis $G U I$ dan $C L I$ kelas X TKJ dan peneliti berperan sebagai observer untuk mengamati berlangsungnya proses belajar mengajar.

\section{Siklus I}

Pada pelaksanaan tindakan siklus I, guru menerapkan model pembelajaran project based learning. Proses pembelajaran ini guru hanya menyampaikan materi yang akan dipelajari dan memberikan materi secara umum, bertindak sebagai nara sumber dan fasilitator, melihat bahwa siswa bisa melaksanakan tugas, membantu kesulitan yang dihadapi siswa dalam pembelajaran. Kegiatan pembelajaran lebih dipusatkan pada peran serta dan aktivitas siswa dalam kegiatan praktik menggunakan.

Pada siklus I siswa dibagi menjadi beberapa kelompok dan masing-masing kelompok beranggotakan 2 siswa. Awal pembelajaran pertemuan 1, guru memberikan pengantar materi yang akan dikerjakan, kemudian siswa bergabung dengan kelompok masing-masing yang telah dibagi. Selanjutnya setiap kelompok diberikan tugas untuk melakukan instalasai sistem operasi Linux yang akan digunakan selanjutnya pada pertemuan 2. Pada pertemuan kedua, siswa melakukan pengerjaan dengan materi yang telah diberikan dengan kelompok masing-masing. Setelah selesai, setiap kelompok membuat laporan hasil pengerjaan yang akan digunakan sebagai nilai psikomotor.

Observer melakukan kegiatan observasi mengenai keaktifan dan afektif siswa. Pada akhir 
siklus I dilaksanakan tes tertulis untuk mengetahui nilai ranah kognitif siswa. Aktivitas belajar siklus I dapat dilihat pada Tabel 1 dan Kompetensi belajar siklus I dapat dilihat pada Tabel 2.

Tabel 1. Aktivitas Belajar Siklus I

\begin{tabular}{lc}
\hline Aspek yang diamati & Presentase $(\%)$ \\
\hline Visual & 8,82 \\
Lisan & 0,58 \\
Mendengarkan & 76,47 \\
Menulis & 17,64 \\
Mental & 20,58 \\
Rata-rata ketuntasan & 58,82 \\
\hline
\end{tabular}

Tabel 1 mengenai hasil aktivitas belajar siklus I tersebut dilihat dari presentase ketuntasan dari data observasi yang telah dilakukan.

Tabel 2. Kompetensi Belajar Siklus I

\begin{tabular}{lcc}
\hline $\begin{array}{c}\text { Hasil } \\
\text { Belajar }\end{array}$ & $\begin{array}{c}\text { Rata-rata } \\
\text { Ketuntasan } \\
(\%)\end{array}$ & $\begin{array}{c}\text { Rata-rata } \\
\text { Tidak } \\
\text { Tuntas(\%) }\end{array}$ \\
\hline Kognitif & 52,94 & 47,05 \\
Afektif & 55,88 & 44,11 \\
Psikomotor & 73,52 & 26,47 \\
Rata - rata & 60,78 & 39,21 \\
\hline
\end{tabular}

Tabel 1 mengenai hasil kompetensi belajar siklus I tersebut dilihat dari presentase ketuntasan dari data observasi yang telah dilakukan. Aktivitas belajar siklus I masih belum memenuhi indikator keberhasilan. Sedangkan kompetensi belajar baik ranah kognitif, afektif, maupun psikomotor juga belum memenuhi indikator keberhasilan sebesar $75 \%$.

\section{Siklus II}

Pada siklus II, dilaksanakan kegiatan pembagian kelompok, sama dengan siklus I. Pembagian kelompok pada siklus II juga sama dengan siklus I. Perbedaan pada siklus II yaitu ketika setiap kelompok sudah selesai mengerjakan proyek, mereka harus presentasi yang kemudian dijelaskan oleh masing-masing kelompok di depan kelas. Kelompok yang mendapat giliran presentasi akan ditanya oleh satu kelompok lain yang bertugas sebagai penanya inti. Presentasi dan kegiatan presentasi ini dijadikan sebagai nilai psikomotor. Observer mengamati aktivitas dan afektif siswa selama pembelajaran berlangsung. Pada akhir siklus II dilaksanakan tes tertulis untuk mendapat nilai kognitif siswa. Aktivitas belajar siklus II dapat dilihat pada Tabel 3 dan hasil belajar siklus II dapat dilihat pada Tabel 4.

Tabel 3. Aktivitas Belajar Siklus II

\begin{tabular}{lr}
\hline Aspek yang diamati & Presentase (\%) \\
\hline Visual & 8,82 \\
Lisan & 17,64 \\
Mendengarkan & 35,29 \\
Menulis & 70,58 \\
Mental & 76,47 \\
Rata-rata ketuntasan & 82,83 \\
\hline
\end{tabular}

Tabel 3 mengenai hasil aktivitas belajar siklus II tersebut dilihat dari presentase ketuntasan dari data observasi yang telah dilakukan.

Tabel 4. Kompetensi Belajar Siklus II

\begin{tabular}{lcc}
\hline Hasil Belajar & $\begin{array}{c}\text { Rata-rata } \\
\text { Ketuntasan } \\
(\%)\end{array}$ & $\begin{array}{c}\text { Rata-rata } \\
\text { Tidak } \\
\text { Tuntas(\%) }\end{array}$ \\
\hline Kognitif & 67,64 & 32,35 \\
Afektif & 76,47 & 23,52 \\
Psikomotor & 88,23 & 11,76 \\
Rata - rata & 77,67 & 22,45 \\
\hline
\end{tabular}

Aktivitas dan Kompetensi belajar siswa pada siklus II secara keseluruhan telah memenuhi indikator keberhasilan sebesar $75 \%$. 


\section{Perbandingan Hasil Tindakan}

Penerapan model project based learning terjadi peningkatan tiap siklusnya. Perbandingan hasil dari siklus I sampai siklus II dapat dilihat pada Tabel 5 untuk aktivitas dan kompetensi belajar siswa. Sedangkan gambar hasil perbandingan tiap siklus dapat dilihat pada Gambar 1.

Tabel 5. Perbandingan Aktivitas dan Kompetensi

\begin{tabular}{lcc}
\multicolumn{3}{c}{ Kompetensi } \\
\hline $\begin{array}{l}\text { Indikator } \\
\text { yang } \\
\text { diamati }\end{array}$ & $\begin{array}{l}\text { Ketuntasan } \\
\text { Siklus I (\%) }\end{array}$ & $\begin{array}{l}\text { Ketuntasan } \\
\text { Siklus II (\%) }\end{array}$ \\
\hline Aktivitas & 58,82 & 82,35 \\
Kompetensi & 60,78 & 77,67 \\
\hline
\end{tabular}

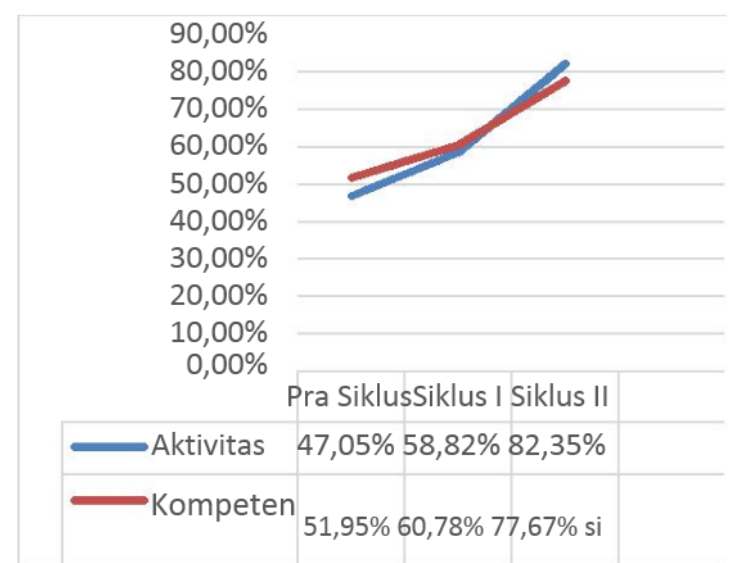

Gambar 1. Perbandingan Aktivitas dan Kompetensi Belajar

Dari data tersebut dapat disimpulkan bahwa penerapan model pembelajaran project based learning dapat meningkatkan aktivitas dan kompetensi belajar siswa. Penerapan model pembelajaran project based learning pada penelitian ini yaitu dengan mengerjakan proyek disertai kegiatan presentasi kelompok dimana setiap kelompok yang maju di depan kelas mempresentasikan hasil pengerjaan proyeknya.

Kegiatan presentasi seperti ini terbukti mampu meningkatkan aktivitas dan kompetensi belajar siswa karena siswa yang berperan sebagai presentator dituntut mengerjakan proyek dengan benar sehingga siswa lebih mengerti materi yang dikerjakan, serta menjadikan siswa lebih bertanggung jawab terhadap dirinya sendiri maupun kelompoknya dan siswa yang berperan sebagai penanya inti juga akan lebih kritis dalam menanggapi kegiatan presentasi serta akan mendapatkan jawaban dari materi yang belum dimengerti melalui pertanyaanpertanyaan yang disampaikan. Sedangkan media pembelajaran membantu siswa lebih memahami materi pada mata pelajaran sistem operasi karena siswa langsung mempraktikkan materi pembelajaran, mencari informasi, dan mengumpulkan data terkait materi yang diinvestigasi serta membantu meningkatkan aktivitas dan kompetensi belajar siswa karena siswa berperan aktif selama proses belajar.

\section{SIMPULAN DAN SARAN}

\section{Simpulan}

Berdasarkan hasil penelitian yang telah dilakukan,maka dapat disimpulkan bahwa (1). Penerapan dengan model Project based learning pada sub tema macam- Menjelaskan langkah Installasi sistem operasi berbasis Command Line Interface (CLI) dan 
Melaksanakan Installasi sistem operasi berbasis

Text sesuai Installation Manual mampu meningkatkan aktivitas belajar siswa. Hal ini terbukti dengan perolehan prosentase kriteria aktivitas belajar siswa, yaitu : pada siklus I sebesar $58,82 \%$ siswa yang mencapai target yang ditentukan (tuntas). Pada siklus II meningkat menjadi $82,35 \%$ siswa yang mencapai keberhasilan sesuai target yang diinginkan. (2) Penerapan dengan model Project based learning pada sub tema macamMenjelaskan langkah Installasi sistem operasi berbasis Command Line Interface (CLI ) mampu meningkatkan kompetensi belajar siswa. Hal ini terbukti dengan perolehan prosentase kriteria kompetensi belajar siswa, yaitu : pada siklus I sebesar $60,78 \%$ siswa yang mencapai target yang ditentukan ( tuntas ) . Pada siklus II meningkat menjadi $77,64 \%$ siswa yang mencapai keberhasilan sesuai target yang diinginkan

\section{Saran}

Berdasarkan penelitian di atas dapat disampaikan saran-saran sebagai berikut : (1). Dalam Pembelajaran berlangsung, guru harus mampu memilih model pembelajaran yang sesuai dengan materi yang akan disampaikan kepada siswa agar siswa mudah dalam memahami dan menerima materipembelajaran; (2). Pembelajaran model Project based learning dapat meningkatkan aktivitas dan kompetensi belajar siswa, maka dalam kegiatan pembelajaran Installasi sistem operasi berbasis GUI dan CLI disarankan menggunakan model pembelajaran tersebut. (3). Guru diharapkan mampu terus mengembangkan semangat siswa dan guru juga perlu menambah wawasannya tentang memahami model - model pembelajaran supaya dapat menciptakan lingkungan pembelajaran yang asik yang inovatif agar pelajaran lebih menarik dan siswa tidak merasa bosan.

\section{DAFTAR PUSTAKA}

A.M. Sardiman. (2011). Interaksi dan Motivasi Belajar Mengajar. Jakarta:Rajawali.

Astuti, R.P. \& Junaedi, I. (2013). Peningkatan Aktivitas dan Hasil Belajar

Daryanto. (2011). Penelitian Tindakan Kelas dan Penelitian Tindakan Sekolah. Yogyakarta: Gava Media.

Djamarah, S.B. \& Zain, A. (2013). Strategi Belajar Mengajar. Jakarta : PT.Rineka Cipta.

Eka ikhsanudin. (2014). Model Pembelajaran project based learning. Diakses dari http://www.ekaikhsanudin.net/2014/09/ model-pembelajaran-projectbased.

html. Pada tanggal 19 April 2016, jam 08.58 WIB.

Hanafiah, Nanang \& Suhana, C. (2010). Konsep Strategi Pembelajaran. Bandung:Refika Aditama.

Hamalik, O (2008). Kurikulum \& Pembelajaran. Jakarta : Sinar Grafika

Hardini, I. \& Puspitasari, I (2012). Strategi Pembelajaran Terpadu (Teori, Konsep \& Implementasi). Familia Pustaka Keluarga.

Jihat, A. \& Haris, A. (2013). Evaluasi pembelajaran. Yogyakarta: Multi Pressindo

Kamdi, W . (2008). Project based learning: Langkah - langkah pembelajaran dalam Project based learning : Universitas Negeri Malang.

Lusi, S. \& Amold, R (2013). Asyiknya Penelitian Ilmiah dan Penelitian Tindakan Kelas. Yogyakarta: Andi Offset

Maliawan, N., Arsa, P.S., \& Ariawan, K.U (2014/2015). Peningkatan Aktivitas dan 
Hasil Belajar Melalui PBL Pada Siswa

Kelas X SMA, Jurnal Penelitian Pendidikan. Penerapan Model Pembelajaran Project based learning (PjBL) Untuk Meningkatkan Hasil Belajar Prakarya Dan Kewirausahaan ( Fisika Terapan) Pada Siswa Kelas X IPA 2 SMA Negeri 1 Sukasaa Tahun Pelajaran 2014/2015, Jurnal Penelitian Pendidikan

Mulyasa. (2011). Praktik Tindakan Kelas. Bandung: PT. Remaja Rosdakarya Melalui PBL Pada Siswa Kelas X SMA, Jurnal Penelitian Pendidikan, 42 (2)

Rezeki, R.D, Nurhayati, N.D., \& Mulyani, S. (2015). Penerapan Model Pembelajaran Project based learning (PjBL) Disertai Dengan Peta Konsep Untuk Meningkatkan Prestasi dan Aktivitas Belajar Siswa pada Materi Redoks Kelas X-3 SMA Negeri Kebak Kramat Tahun Pelajaran 2013/2014. Paedagogia : Jurnal Penelitian Pendidikan, 4 (1) 74 81

Siyamta. (2013). Sistem Operasi. Jakarta: Kementrian Pendidikan dan Kebudayaan.

Suradji. (2008). Strategi Belajar Mengajar. Surakarta : UPT Penerbitan dan Percetakan (UNS Press).

Suwarto,WA. (2014). Model - Model Pembelajaran Berwawasan Lingkungan Hidup. Surakarta : Pelangi Press. 